International Journal of Trend in Scientific Research and Development (IJTSRD)

Volume: 3 | Issue: 3 | Mar-Apr 2019 Available Online: www.ijtsrd.com e-ISSN: 2456 - 6470

\title{
Rethinking Gandhian Principles in Post Colonial Era
}

\author{
Krishnanunni R ${ }^{1}$, Vishnu Achutha Menon² \\ ${ }^{1}$ Post Graduate Student, ${ }^{2}$ Doctoral Scholar \\ ${ }^{1}$ MA International Relations, Department of Political Science and Public Administration, \\ 1 University of Madras, Chepauk, Chennai, Tamil Nadu, India \\ 2Department of Media and Communication , Central University of Tamil Nadu, \\ ${ }^{2}$ Neelakudi, Thiruvarur, Tamil Nadu, India
}

\begin{abstract}
How to cite this paper: Krishnanunni $\mathrm{R}$ | Vishnu Achutha Menon "Rethinking Gandhian Principles in Post Colonial Era" Published in International Journal of Trend in Scientific Research and Development (ijtsrd), ISSN: 24566470, Volume-3 | Issue-3, April 2019, pp.286-289, URL: http://www.ijtsrd.co $\mathrm{m} /$ papers/ijtsrd217 50.pdf

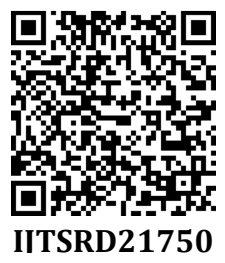

Copyright (C) 2019 by author(s) and International Journal of Trend in Scientific Research and Development Journal. This is an Open Access article distributed under the terms of the Creative Commons

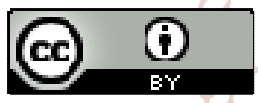
Attribution License (CC BY 4.0) (http://creativecommons.org/licenses/ by $/ 4.0$ )

Gandhi and the notion of Satyagraha Satyagraha is a Sanskrit and also a Hindi word which is a synonym to the quest for truth" is an idea presented in the mid-twentieth century by Mahatma Gandhi to assign peaceful protection from the malevolence of British. Gandhi's satyagraha turned into a noteworthy device in the Indian battle against the British government and has since been embraced by dissent bunches in different nations.

As per this theory, followers of satyagraha, imbibe right understanding into the genuine idea of an insidious circumstance by observing peacefulness of the psyche, by looking for truth in a soul of harmony and love, and by experiencing a thorough procedure of self-examination. In this manner, the satyagrahi experiences truth in the total. By declining to submit to the wrong or to coordinate with it in any capacity, the satyagrahi states that fact. All through the showdown with fiendishness, the satyagrahi must cling to peacefulness, for to utilize savagery is lose right knowledge. Satyagrahis dependably caution the rivals of their expectations; satyagraha disallows any strategy proposing the utilization of mystery further bolstering one's good fortune. Satyagraha incorporates more than common disobedience. Its full scope of utilization reaches out from the subtleties of right day by day living to the development of option political and monetary foundations. Satyagraha tries to overcome through change last, there is neither thrashing nor triumph yet rather another amicability. Satyagraha draws from the antiquated Indian perfect of ahimsa ("noninjury"), which is sought after with specific thoroughness by Jains, a large number of whom live in Gujarat, where Gandhi grew up. Informing ahimsa into a cutting edge idea with expansive political results, as satyagraha, Gandhi likewise drew from the works of Leo Tolstoy and Henry David Thoreau, from the Bible, and from the Bhagavadgita, on which he composed his own critique.

When the world is bathed in blood, where history has only tales of violence to share, an old skinny man nicknamed as a 'half naked fakir' by world renown bureaucrat Winston Churchill demonstrated to the world that victory over the oppressor can be non-violent methods too. Mohandas Karamchand Gandhi, Mohandas Karam Chand Gandhi also known as Mahatma Gandhi is one among the pioneers against the freedom struggle against the oppressive British regime across India which looted and plundered India to its nadir for almost two centuries. Born and brought up in a Gujarati Hindu family, Gandhi pursued his honours in Law from London, he worked in Mumbai and Rajkot for short span and moved to South Africa in order prosper in his carrier as a lawyer. Gandhi initially started his social 
activism by indulging in issues such as racial discrimination and problems regarding trade and movement of the Indian community present there. Within a short span of time, Gandhi made news headlines for his movements, but his popularity was limited to a trifling number. Regardless of his popularity, his modus operandi of non-violence, which he called to be 'sathyagraha', 'quest for peace' gained wider momentum.

As time rolled, he returned back to India, where an urge for a national movement was ushered across the nation, Gandhi was the chosen one to lead the campaign. Gandhi began unifying worker, and other labourers in order to challenge ridiculous land-assessment and segregation act of the British regime. After the formation of Indian National Congress in 1921 and Gandhi being a primo in its formation, Gandhi escorted across the country crusades for different social causes and for accomplishing 'Swaraj' or self-rule. Gandhi drove Indians in testing the British-forced salt expense with the $400 \mathrm{~km}$ 'Dandi Salt' March in 1930, and later a movement requiring the British to Quit India in 1942. He was detained in jail for a long time, upon numerous events, in both South Africa and India for ushering protest against British colonial regime for ensuring civil rights.

Critics of satyagraha, both in Gandhi's period and later on, have contended that it is impractical and incompetent of universal success since it relies upon a high standard of virtuous conduct and demands an idealistically strong level of obligation from those struggling for social enhancement.

According to Gandhi, "An eye for an eye makes the entire world visually impaired" on his notion of peacefulness. His strategies and standards had impacted numerous pioneers like Martin Luther King, James Lawson, and Nelson Mandela to name a few. Indeed, even right up 'til today the world needs an individual like Gandhi to realize an insurgency, a development to end psychological warfare, destitution, and to spread the astuteness of Ahimsa. He is known as Mahatma (Great Soul) and Bap) by all Indians living around the world. Gandhi has openly declared he should never be considered a saint or a philosopher because he moreover considers him to be a scientist who loves to experiment with truth. Gandhi also asserted that his principles should be essentially modified according to times as time passes on. The significance of Gandhi's preaching is still relevant, amidst the underlying criticism in the world which is peddling on the clutches of violence across the world.

As per Gandhi's preaching, the act of untouchability is an injury in the entire clan of Hindu culture. He made it his life's main mission to wipe out the menace of untouchability and to inspire the underprivileged class. Being a gospeller of humankind, he envisioned that every single person is equivalent and consequently the Harijans also have an equal privilege for public activity alongside other public gatherings. For Gandhi live was 'yajna' (penance) rather than something ordinary. He considered it to be an auspicious sacrifice for others without craving in return, regardless of spiritual or material in nature.

\section{Panchayati Raj}

India is celebrating the 25th anniversary of 'Panchayati Raj' institutions, which was officially amended in 1992 under the Indian Constitution for enhancing decentralization to villages. When we look back, the system played a pivotal role in bringing modern reforms in villages as well as a failure in not implementing several programs.

Mahatma Gandhi's vision of 'Grama Swaraj' (freedom of the villages) is deeply ingrained his views on Panchayati Raj, which ensures autonomy to villages in dealing with issues and uplifting itself from all the servitudes of past and making the seven lakh villages in India self- sustainable and eradicate poverty in a cooperative holistic manner. As per the words of Mahatma Gandhi , who pioneered in advocating 'Panchayati Raj' for the first time in India asserted that "The soul of India lies in the Villages" and his set of tutelages on 'Panchayati Raj', published by Navajeevan Publishing House in 1959 prescribes his insights on 'How an ideal village, should function'. Throughout the series, Mahatma Gandhi elucidates his optimistic views on villages, where he says that whoever wishes to know the villages should come out leaving their money-making fantasy and with an attitude of service can play a crucial role in restoring the pomp and pride of villages. In his dreams he exclusively neglects the notion poverty-stricken India and an abode of illiterates and avows for self-reliance in acquiring proper food, clothing, and sanitation .where they can manage their lives by themselves, where these values play the key role in determining the progress of the nation.

Mahatma Gandhi asserts that the practice of republic villages and 'gram panchayats 'can be traced from our own history and how effective they were dealing with the issues of the society. But with the coming of British to India, the idea of a republic was snatched and curtailed to mere tax collection institution which enhanced their plunder. But for the first time, at the period of British rule, India tried to introduce 'Panchayati Raj' in 1921, which failed drastically and Gandhi was very optimistic that eventually, this scheme will find root in a gradual process and as history unravelled, 'Panchayati Raj' was officially demarcated under the Indian constitution giving voice to the people of villages. In the preindependent era itself Gandhi has mapped out the qualification of an effective 'Panchayati Raj' system on how election should be conducted and what are the duties of an elected body in a panchayat ensuring equality to all and in independent India, he advocated equality as considering each human being as a unit which encompasses women rights and equal labour to all. According to him, a village has been resilient enough to defend itself from an onslaught and it should work on the principles of truth and non-violence. Each and every religion has its own place in villages. Gandhi was also against the mechanization of village labour, which is quietly debatable, where today in globalized world life without technology is undeniable. But looking from upliftment of women in today's context, the nation has most women in elected posts.

In his vision of an ideal village, Gandhi envisions the villages to self-reliant in addressing its own needs, which it grows food, cotton for its own need and each village should have its own recreation centres and education centre all. Gandhi advocates everyone in a cooperative manner and protection of villages should take care by the villages themselves. He vows proper election should be conducted based on proper norms. At present, in India, there are 250,000 Panchayat Raj institutions and around three million local elected representatives nationwide. 
The economy of a village has to be based on truth and has to completely eschew exploitation and every person of the village should strive for the progress of the village rather than working for the selfish and vested personal interest. In the present context, the rural-urban divide where villagers are exploited in all possible ways, especially the increasing farmer suicide tolls in the nation is a classic example for the exploitation and Karnataka pioneers in farmer suicide with a rate of 36 per cent in 2015.

Gandhi asserts that elementary education has to be provided for all and he dream of villages with this he dreams of villages which will eventually turn into a conglomeration of people from various disciplines. The art, craft, education, and education has to knit together on a thread in the resurrection of villages. The people have to be also sensitized on the need for proper sanitation. Moreover to that, education has to be the prior concern and women too should receive equal rights as men do. Currently, Indian villages are surpassing the barriers of education that 70 per cent of the population between the ages of 16-18 is attending schools and colleges. Gandhi hereby vows to learn a common language for all, which is Hindi, which considered to National language and annuls the infatuation for the English language. This view is a contradictory one where Constitutionally India does not have a national language and to great extent, it is devaluing the emotion of non-Hindi speakers.

Sanitation is considered with prior importance by Gandhi, where he recommends that to wield up a health and sustainable village, proper sanitation mechanism has to be adopted in achieving this mission. Gandhi recommends for proper sewage mechanisms and ways to curtail water pollution. In his view, a large proportion of waste can be classified an used as manure for agriculture and some are refurbished such as plastics and papers. Gandhi asserts that the villagers themselves have to take charge of themselves in making this possible. The concept of 'Swatch Bharath Abhayan' is adapted from Gandhi. But even though the government lays several claims of achieving the target of curtailing open defecation, still authentic reports are yet to come and still, no measures are yet drawn in enhancing the manual scavenging folks. The scheme has the too long way to go in sensitizing villagers on how both human excreta and animal dung can be used as ideal manure for agriculture, where rampant use pesticides are increasing day by day, which may lead to health catastrophe. Sanitation has a lot to do with health, where he asserts that it is impossible to attain 'Swaraj' without proper health. Gandhi says nature is abundant with resources and ask the villagers to adopt natural remedies than going to the chemist. But looking at today's broadcast, the urban-rural divide high, where a UN report shows that 75 per cent of health infrastructure is focused on urban cities and in some cases it even becomes unaffordable.

Gandhi specifically speaks about the importance of cooperative cattle farming in villages and he asserts specifically on how proper care should be given to cattle on the basis of both humanitarian concern as well as religious. Its health and food are unavoidable are should of prior concern. The concept of 'White Revolution', which was initiated in 1970 is considered to be the world's largest dairy production initiative, flipping the nation to be the largest producer of milk. But the present obsession of a certain wing of people who themselves assume to the 'cow protectors' is demeaning both the notion nonviolence prescribed by Gandhi and has already begun taking law in their hands, which has resulted in the death of 29 people since 2012, exclusively in regard to cow politics. The concept of 'gow seva' is misspelt as a license to even take life in the name of fanaticism.

The role of a 'Congress ministers' is exclusively prescribed by MK Gandhi, is to support the people when there is a dire need of clothing and food. The villagers have to sensitize in manufacturing their own 'Khaddar' for their own use and the government will assist them in their mode of production. The people of the village will be encouraged in the production of other indigenous products to and the government will aid in ushering them to the market. One of the biggest failures of 'Panchayati Raj' today is that is the case of revenue generation and no proper attention is paid by the financial commitment to procuring funds to grassroots as the well as the state government, who is bound to the recommendations of the finance committee. Now, the ruling government, which is led by NDA too, is failing to push the villages' one step further. The recent trend shows, the Congress ministers turn richer as the farmers even poorer. The suicide rates which sums up to 12,000 plus since 2013 is a symbol of the shambolic disgrace of the ruling government's inability to deal with the crisis of farmers. The recent Protest organized by farmers which turned to be turbulence between the cops too illustrates the government's inefficiency in dealing with the issues faced by the farmers and we see increased rates of protest by the farmers nationwide.

As Gandhi often aspires to knit people altogether, Gandhi speaks of certain intuitions such as Lok Seva Sangh, with a motto of ' universal aid ' of helping people overcome the social stigma and dogmas, which ensures equality to all sex without concern of their of cast or creed. They will be educated on sanitation, self-procurement.The importance of Khadi wearing much used Gandhi's works, which the importance is often perishing. Gandhi also speaks about 'Samagra Gram Sevana' where he asks the people unify themselves and procure whatever is essential for the suitability of the village community. Gandhi, again and again, stresses upon the need for hygiene and sanitation.

Gandhi as a preacher of nonviolence insisted on the need of 'Santi dals ', where is set of people are knit to together in making sure the message of peace reaching till the grass root level. The peacekeeping force will never carry any arms and he should be equipped to address any grievance. But today, India is a domicile of several 'Ashanti Dals', where people are even daring to take the lives of people, for example, and the 'cow vigilantes 'as earlier mentioned above. .The state moving on the euphoria of intolerance and the cases of scathing attacks on fellow beings are at its peak.

We look at Gandhi's views on 'Panchayati Raj', in the present context, the nation has a long path to reach par excellence. In a technological age, life without technology is unimaginable, where several procedures of 'Panchayati Raj' are undertaken online and which has made life easier for the common man. From a vantage point, the substratum of Gandhi's upholds great insights, but unless it's not enacted, the thoughts would remain ' utopian'. 


\section{Ahimsa}

Ahimsa or peacefulness is the weapon utilized by Gandhi to free India from the British Rule. Ahimsa is a Sanskrit expression content intending no mischief, truly the avoidance of savagery (himsa). Ahimsa began from antiquated India and is refined in Hinduism, Buddhism and Jainism. As specified by the ancient folklore, Ahimsa is a set of accepted rules that ban on, killing, butchery, meat eating and utilization of items acquired by vicious methods.

Gandhi utilized this modus operandi against the British as a major weapon in the Indian Independence development. He trusted that the most ideal approach to opposing oppression is through nonviolence and civil disobedience, which is established upon Ahimsa. Gandhi began Noncooperation development by challenging the British-forced salt expense with the $400 \mathrm{~km}$ Dandi Salt March. Gandhi could recognize the genuine rationale of the East India Company that was trade and business, henceforth he chose to blacklist every single foreign item and urged the citizens to abandon every single one of them. He at that point began the Quit India movement $\mathrm{t}$, which turned into the most commanding development in the historical backdrop of the Indian battle for independence, with mass arrests and violence on an exceptional scale. He needed his supporters to pursue the standards of Ahimsa. He requested that the Indians be peaceful amid the challenges and stay away from any brutality that is started by the British. The development united the whole country which left the East Indian Company deadened. At midnight on fifteenth August 1947 India turned into an autonomous country and on fourteenth August 1947, Pakistan has proclaimed a different country with the Muslim larger part. Gandhi's everything endeavours to keep India joined went purposeless. In any case, even right up 'til today as the Indians set themselves up to commend their autonomy day on fifteenth August, the Indians everywhere throughout the world recollects Gandhi for his battle and penance to free India from bondage, neediness and end unapproachability.

\section{Conclusion}

We are living today in a time where social, social and political circles are bereft of otherworldliness. Be that as it may, Gandhi's peacefulness still offers us a perfect that may maintain. Gandhi remains the prophetic voice of the 21st century and his peacefulness urges us to keep battling for the benefit of what we see as right and just. When humanity is gone up against conflicts of national intrigue, religious fundamentalisms and ethnic and racial preferences, peacefulness can be an all-around confided in methods for laying the foundation of another cosmopolitics. In spite of the fact that many keeps on trusting that peacefulness is an ineffectual instrument against tyrannies and slaughter, over the most recent quite a few years numerous law based activities, which were prefaced on peaceful militancy and an insistence of human rights and helped construct worldwide common society on strong moral establishments, could be related with a sort of neo-Gandhian mission for harmony and equity.

It is uncovering that in this present reality where there are catastrophes, for example, fear-based oppression, neediness, lack of education and devotion, history can, in any case, be settled on out of decisions. The decision of peacefulness is our own. We live in a universe of "covering predeterminations" where the destinies of societies are intensely interlaced. It is never again a universe of shut networks where overbearing requests or religious customs spoke to the sole layers of chronicled authenticity. Never in the historical backdrop of mankind has peacefulness been so urgent. Just the most primitive and oppressive routines, be that as it may, have endeavoured to keep their subjects to think and to rehearse peacefulness.

Peacefulness has as of late developed from a straightforward strategy of protection from a cosmopolitical point dependent on global use of the standards of vote based system. In the course of recent decades, worldwide fear based oppression, infringement of human rights and natural corruption have caused repercussions featuring the worry for worldwide legislative issues of peacefulness. These can best be managed at the worldwide dimension. Worldwide legislative issues of peacefulness, along these lines, is the errand of governments as well as of common society, and between administrative, non-administrative and transnational associations. In particular, the universal network has the ethical commitment and obligation to mediate in nations in the event that they slide into the wilderness and can't shield natives from infringement of human rights. Just a peaceful society can stir its way up to making the foundations ready for improvement and lead to between social and between religious agreement. In a century where fear conditions the life and attitude of no less than $66 \%$ of mankind and savagery impacts our regular culture, we can't proceed with the strategy of the ostrich-having surrendered inquisitive "whose obligation it is?", it is ours.

\section{Bibliography}

[1] Gandhi, M. (1932). From Yervada Mandir. Ahmedabad: Navajivan Publishing House.

[2] Gandhi, M. (1948). Key To Health. Ahmedabad: Navajivan Publishing House.

[3] Gandhi, M. (1959). Panchayat Raj. Ahmedabad: Navajivan Publishing.

[4] Gandhi, M. (1959). The Moral Basis of Vegetarianism. Ahmedabad: Navajivan Publishing House. 